\title{
Determining Salinity and Ion Soil Using Satellite Image Processing
}

\author{
Evangelina Ávila Aceves ${ }^{1}$, Héctor José Peinado Guevara ${ }^{2}$, Adriana Cruz Enríquez ${ }^{1}$, \\ José de Jesús Campos Gaxiola ${ }^{1}$, Manuel de Jesús Pellegrini Cervantes', \\ Jaime Herrera Barrientos ${ }^{3}$, Leonardo Esau Herrera ${ }^{3}$, \\ Víctor Manuel Peinado Guevara ${ }^{2 *}$, Campista León Samuel ${ }^{4}$
}

\author{
${ }^{1}$ Facultad de Ingeniería Mochis, Universidad Autónoma de Sinaloa, Fuente de Poseidón y Ángel Flores s/n, \\ Jiquilpan, Los Mochis, Sinaloa, México \\ ${ }^{2}$ Escuela de Ciencias Económicas y Administrativas, Universidad Autónoma de Sinaloa, \\ San Joachín, Guasave, Sinaloa, México \\ ${ }^{3}$ Centro de Investigación Científica y de Educación Superior de Ensenada, Baja California (CICESE), \\ Ensenada, México \\ ${ }^{4}$ Escuela de Biología, Universidad Autónoma de Sinaloa, Culiacán Sinaloa
}

Received: 13 November 2017

Accepted: 2 January 2018

\begin{abstract}
Arid and semi-arid zones frequently present salinity problems in soils. The agriculture of the municipality of Ahome, Sinaloa has an agricultural region where its soils are characterized by problems of salinity and sodicity - conditions that reduce production. Salinity can be detected by implementing remote sensing techniques; there are ways to enhance the detection of satellite salinity through the use of diverse quantitative models, using the spectral signature of each of the components of the study area through algorithms named indices. For this study we used the normalized differential salinity index (NDSI) from a Landsat OLI image for the southern area of the city, which is related to the electrical conductivity $(\mathrm{EC})$ of the soils $(\mathrm{R}=0.90)$. At the same time, it is related to some anions and cations. As a result, it is possible to determine since the NDSI, the anion $\mathrm{Cl}-$ and Cations $\mathrm{Na}+, \mathrm{Ca}++$, and $\mathrm{Mg}++$. We found a relationship between $\mathrm{EC}-\mathrm{Cl}-(\mathrm{R}=0.94), \mathrm{EC}-\mathrm{Na}+(\mathrm{R}=0.84)$, $\mathrm{EC}-\mathrm{Ca}++(\mathrm{R}=0.85)$, and $\mathrm{EC}-\mathrm{Mg}++(\mathrm{R}=0.86)$. The electrical conductivity in the field and laboratory, anions, cations, and NDSI index were filtered with the Kalman filter obtaining better fitter, eliminating dispersivity in the variable relations.
\end{abstract}

Keywords: NDSI, salinity, electric conductivity, anions, and cations

*e-mail: v_peinado@hotmail.com 


\section{Introduction}

It is estimated that between 20 and $30 \%$ of soils worldwide are affected in varying degrees by salinity [1], causing environmental problems, mainly in agriculture [2]. The main factors that cause salinity in soils are the weathering of minerals and the high levels of the phreatic level with high concentrations of salt and surface water [3].

Arid regions are prone to accumulate soluble salts in close vicinity to the surface. There are different forms of salinization of soils, they are classified as primary and secondary; primary salinization consists of the development of salts through natural processes, geological deposits, and physical and chemical erosion that cause the movement of ions $\mathrm{Ca}^{++}, \mathrm{Mg}^{++}, \mathrm{Na}^{+}[3,4]$.

On the other hand, secondary salinization is caused by human interference in production processes, inadequate irrigation practices, and poor drainage conditions [3, 4], which promote the enrichment of soluble salts and the decrease in the productivity of agricultural lands with irrigation systems [5, 6]. Salinization of soils should be addressed, so information on its scope and magnitude is required for better planning and implementation of effective recovery programs [8].

Salinity can be detected by implementing remote sensing techniques [9]. The salinity process is not exclusive to the surface, but to the whole profile, causing a limitation in the use of optical sensors [10]. However, there are ways to potentiate salinity detection by satellite through the use of diverse quantitative models, using the spectral signature of each of the components of the study area [10-13]. Wu et al. [14] used images of the Landsat and SPOT satellites in Iraq with which they handled the NDVI indices and soil vegetation adjustment index (SAVI), and estimated the electrical conductivity of the soil through the indices. Subsequently, Zewdu et al. [15] estimated and mapped salinity in southern Ethiopia with four classes of soil affectation according to FAO.

Wu et al. [14] used images of the Landsat and SPOT satellites in Iraq with which they handled the NDVI indices and soil vegetation adjustment index (SAVI), and estimated the electrical conductivity of the soil through the indices. Subsequently, Zewdu et al. [15] estimated and mapped salinity in southern Ethiopia with four classes of soil affectation according to FAO.

Soca et al. [16] worked on determining salinity degradation on farmland using images from the Spot, Landsat 5, and Landsat 7 satellites for the northern coast of Peru. Poenaru et al. [17] worked to determine the sensitivity of remote sensing of the Landsat 8 satellite in the identification of saline zones for the care of crop lands. Their results show that saline soils have a higher reflectance in all bands of the images as well as that the NDVI index presents better values in estimating the quality of the crops and in the classification of those whose soils are affected by salinity.
Some authors have indicated in Table 1 (indices for the determination of salt areas) the use of mathematical algorithms for the satellite images spectral bands in order to emphasize and facilitate the detection of the zones affected by salt. Among them stands out the normalized differential vegetation index (NDVI), the normalized differential salinity index (NDSI), and the brilliance index (BI), as well as several variants of the index of salinity.

Among the publications made with the use of these indices, several authors agree that the application of both NDVI and NDSI obtain similar results in the detection of salt areas [1, 3, 18-21]. However, most of them avoid using NDSI, despite having this algorithm closer to the process of salinization in soils and more related to the electrical conductivity of the same [1, 6, 18-21].

On the other hand, the passage of electric current through a saline solution is found in function of the concentration of salts and temperature; salinity of an extract can be characterized by measuring electrical conductivity (EC) with the use of a conductivity meter in laboratory [5]. Thus, the total dissolved salts are located in the space, due to the high values of electrical conductivity presented by the soil [22].

Mora et al. [23] analyzed the values of salinity by means of electrical conductivity, present ions $\left(\mathrm{Ca}^{2}+\right.$, $\mathrm{Mg}^{2}+, \mathrm{Na}+$ ), and sodicity through the ratio of sodium uptake and alkalinity by $\mathrm{pH}$ in a semi-arid irrigation district in Spain. The results of the measurements showed soils with a gradual increase of electrical conductivity that translates to higher concentrations of sodium throughout the temporary study.

This study aims to create a map identifying the presence of salts present in the soil beginning from the salinity and vegetation indices (NDSI and NDVI respectively) of the images of Landsat 8 , in addition to measurements in situ of $\mathrm{EC}$, humidity, $\mathrm{pH}$, and laboratory analysis.

\section{Study Area}

This work was accomplished in an agricultural land lot from the municipality of Ahome, Sinaloa, Mexico. In the study area, very dry climate is predominant, very warm and warm with summer rains and an average annual temperature of $25.3^{\circ} \mathrm{C}$ for the series 1986-2015 [24], located between the meridians $108^{\circ} 59^{\prime \prime} 1^{\prime \prime}$ and $109^{\circ} 06^{\prime} 19^{\prime \prime}$ west and the parallels $25^{\circ} 38^{\prime} 25^{\prime \prime}$ and $25^{\circ} 466^{\prime \prime}$ " north (Fig. 1). The total annual mean precipitation of $357.7 \mathrm{~mm}$ is for the series 1981-2010 [25]. The surface in the study area comes from the Cenozoic era of the quaternary period and the chromic Vertisol soil predominates, which is present in the area of study having medium and high fertility; however, it can present problems of drainage and salinity. These are cases where they are dry and found in place of plastics and sticky. The study of the soils in the region undoubtedly represents an alternative to mitigating problems related to agricultural management 


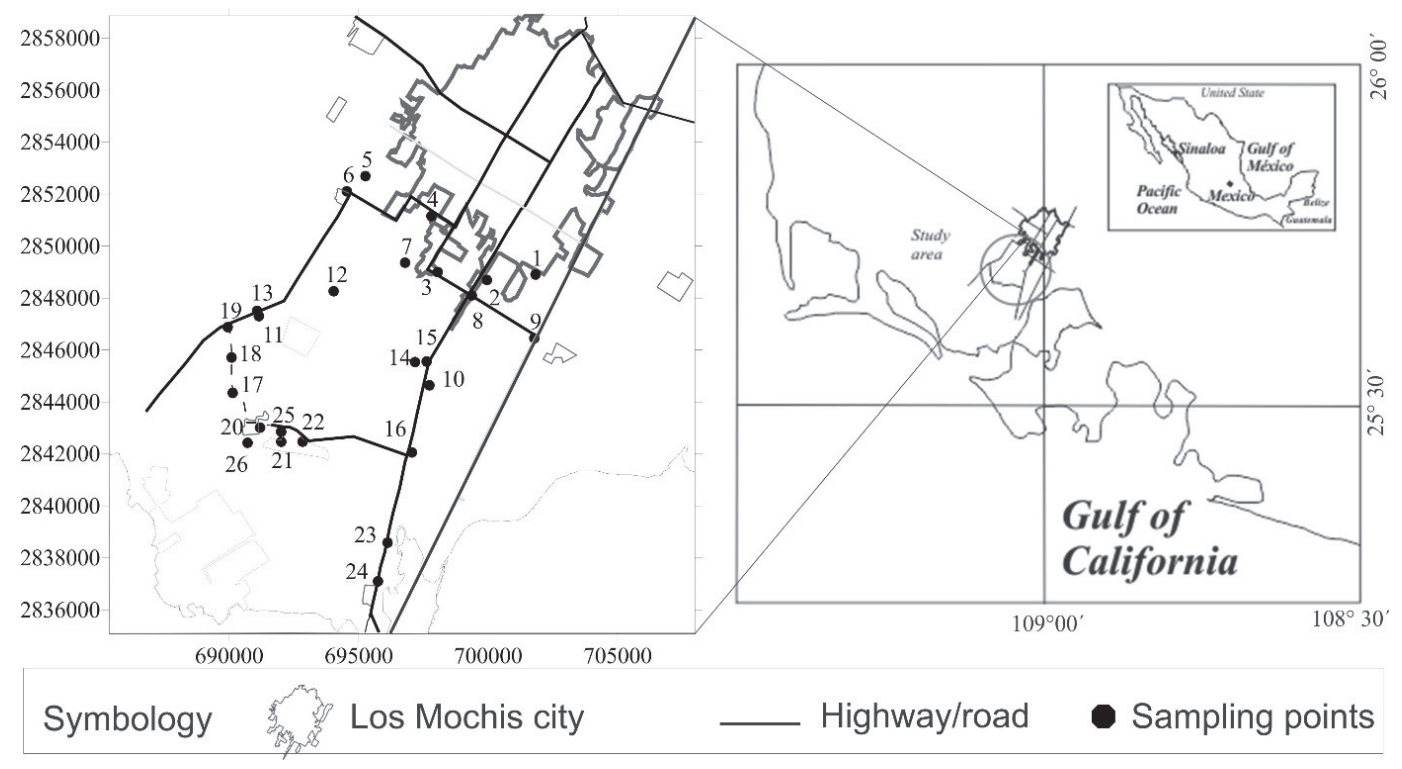

Fig. 1. Location of the study area.

and risks in livestock farming and construction [25]. Additionally, the majority of the study area presents $\mathrm{pH}$ between 6.5 and 7.5, although in salt-affected soils this varies depending on the saline concentration of this one, specifically of sodium. Nevertheless, the region is characterized by its agricultural activity, and among its main crops are potato, sorghum, mango, corn, and beans [26].

\section{Materials and Methods}

Fig. 2 shows the methodology used in the present work, where it can be observed that the soil salinity can be estimated by satellite image processing, directly through measurements in situ or through the extraction of soil samples, and determine it in the laboratory, which in turn are related to some anions and cations previously filtered with the Kalman filter. The soil features of the study area are presented in a table of basic statistics.

The image of the Landsat 8 OLI satellite was consulted on the United States geological website (USGS) [27] dated June 2016, and location Phat 33, Row 42 , in the area corresponding to the study area. Through the software Idrisi Selva 17.0, the bands were adjusted to the bands of the image, using the command Histo and Strech, bands belonging to the visible and near infrared spectrum were respectively measured and cut, that is bands 2, 3, 4, and 5 also perfored them a lineal stretching to their histograms with a $2.5 \%$ saturation. With the window function, the image was trimmed to the geographic size of the study area and the BI, NDSI, NDVI, and WATER indices were created with Image Calculator, whose equations are shown in Table 1.

Twenty-six control points were determined with which physical soil parameters were requested. In each of them, wells were made at $30 \mathrm{~cm}$ depth, from which $3 \mathrm{~kg}$ of soil sample were extracted, and then with a portable conductivity meter HI 98331 Hanna Instruments brand, electrical conductivity readings were taken in situ (Fig. 1). Saline concentration of the soil depends on the type of soil and the moisture that it contains, so the equipment measures the ion concentration of the soil dissolution in function of its chemical composition and its property for retaining water and the chemical elements that it has [34]. The points were geo referenced with a GPS navigator.

Soil samples were subjected to a drying, milling, and sieving process. According to the official Mexican standard NOM-21-RECNAT-2000 [35], the detection of soluble ions and electrical conductivity was performed in laboratory. For determining the soil texture we used the Bouyoucus technique [36]. In the Statistica 7 software, statistical relationships of the variables (previously filtered as indicated in the following section) were realized, obtaining a correlation matrix between

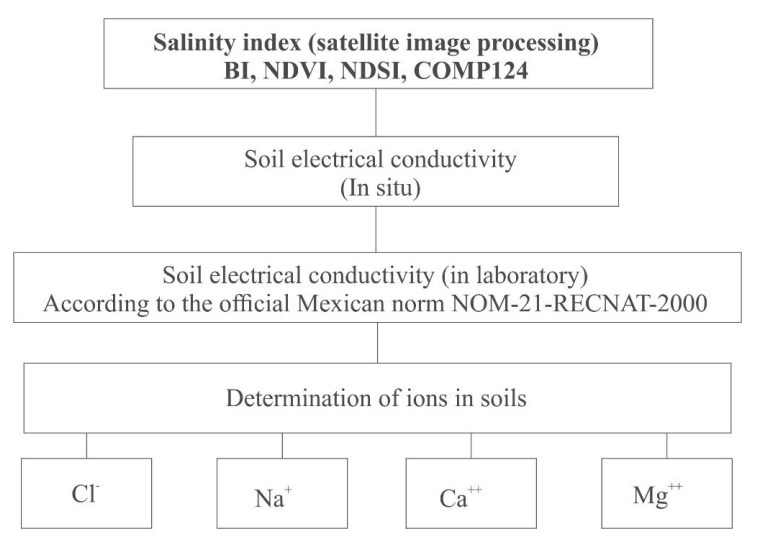

Fig. 2. Methodology applied for determining salinity, and some anions and cations from satellite image processing. 
Table 1. Indices for determining saline zone

\begin{tabular}{|c|c|c|}
\hline INDEX NAME & FORMULA & REFERENCE \\
\hline Brightness Index (BI) & $\sqrt{R^{2}+N I R^{2}}$ & {$[1,21]$} \\
\hline Normalized Differential Salinity Index (NDSI) & $\frac{R-N I R}{R+N I R}$ & {$[18,21,28-33]$} \\
\hline Normalized Differential Vegetation Index (NDVI) & $\frac{N I R-R}{N I R+R}$ & {$[1,2,10,15]$} \\
\hline WATER & $\frac{\operatorname{CoMP} 124}{N I R(\operatorname{strech~} 2.5 \%)}$ & {$[19]$} \\
\hline
\end{tabular}

Where R: red band, B: blue band, G: green band, NIR: near infrared band

Table 2. EC test results in situ and salinity indices (NDSI, NDVI, BI, water).

\begin{tabular}{|c|c|c|c|c|c|c|c|c|}
\hline \multirow{2}{*}{ Point } & \multirow{2}{*}{$\mathrm{X}$} & \multirow{2}{*}{ Y } & EC in situ & EC in laboratory & \multirow{2}{*}{ NDSI } & \multirow{2}{*}{ NDVI } & \multirow{2}{*}{ BI } & \multirow{2}{*}{ WATER } \\
\hline & & & $\mathrm{mS} / \mathrm{cm}$ & $\mathrm{mS} / \mathrm{cm}$ & & & & \\
\hline 1 & 701831 & 2848909 & 0.93 & 1 & -0.1469 & 0.1469 & 27816.7 & 40.0 \\
\hline 2 & 699951 & 2848698 & 0.67 & 8.4 & -0.1633 & 0.1633 & 27371.6 & 39.5 \\
\hline 3 & 698053 & 2849001 & 2.05 & 5 & -0.1383 & 0.1383 & 26424.6 & 39.9 \\
\hline 4 & 697807 & 2851161 & 2.75 & 10 & -0.1423 & 0.1423 & 27714.7 & 40.5 \\
\hline 5 & 695263 & 2852699 & 0.51 & 1.5 & -0.1271 & 0.1271 & 27837.4 & 40.6 \\
\hline 6 & 694546 & 2852113 & 1.3 & 3.3 & -0.1718 & 0.1718 & 27503.5 & 39.7 \\
\hline 7 & 696793 & 2849366 & 3.95 & 10.5 & -0.1146 & 0.1146 & 28013.9 & 39.8 \\
\hline 8 & 699369 & 2848103 & 0.82 & 3.9 & -0.1637 & 0.1637 & 28245.3 & 39.7 \\
\hline 9 & 701782 & 2846455 & 0.98 & 1.5 & -0.1512 & 0.1512 & 26893.7 & 41.7 \\
\hline 10 & 697731 & 2844644 & 2.04 & 4.5 & -0.1681 & 0.1681 & 27213.0 & 40.6 \\
\hline 11 & 691151 & 2847308 & 0.14 & 6.9 & -0.1718 & 0.1718 & 27374.9 & 40.3 \\
\hline 12 & 694037 & 2848268 & 2.99 & 9.4 & -0.1366 & 0.1366 & 26668.6 & 40.4 \\
\hline 13 & 691079 & 2847513 & 2.83 & 7.6 & -0.1377 & 0.1377 & 25794.5 & 39.8 \\
\hline 14 & 697176 & 2845538 & 4.44 & 8 & -0.1201 & 0.1201 & 27548.4 & 39.6 \\
\hline 15 & 697625 & 2845561 & 6.19 & 10.6 & -0.1337 & 0.1337 & 26988.7 & 40.4 \\
\hline 16 & 697055 & 2842063 & 3.77 & 10.4 & -0.1409 & 0.1409 & 25304.7 & 40.5 \\
\hline 17 & 690137 & 2844353 & 11.43 & 39 & -0.0895 & 0.0895 & 24303.9 & 40.9 \\
\hline 18 & 690095 & 2845716 & 12.12 & 43 & -0.0707 & 0.0707 & 24061.7 & 41.2 \\
\hline 19 & 689946 & 2846885 & 12.17 & 46 & -0.0749 & 0.0749 & 26051.6 & 41.4 \\
\hline 20 & 691192 & 2843015 & 7.14 & 34 & -0.133 & 0.133 & 27993.3 & 40.6 \\
\hline 21 & 692010 & 2842474 & 8.46 & 35 & -0.0984 & 0.0984 & 27655.0 & 40.3 \\
\hline 22 & 692836 & 2842475 & 9.06 & 23 & -0.0918 & 0.0918 & 26661.3 & 40.7 \\
\hline 23 & 696117 & 2838589 & 7.95 & 25 & -0.1024 & 0.1024 & 25271.6 & 40.7 \\
\hline 24 & 695747 & 2837102 & 12.68 & 49 & -0.0699 & 0.0699 & 24537.8 & 41.0 \\
\hline 25 & 692009 & 2842860 & 11.15 & 41 & -0.0979 & 0.0979 & 24607.6 & 40.9 \\
\hline 26 & 690711 & 2842432 & 2.41 & 7 & -0.1228 & 0.1228 & 27394.7 & 39.8 \\
\hline
\end{tabular}



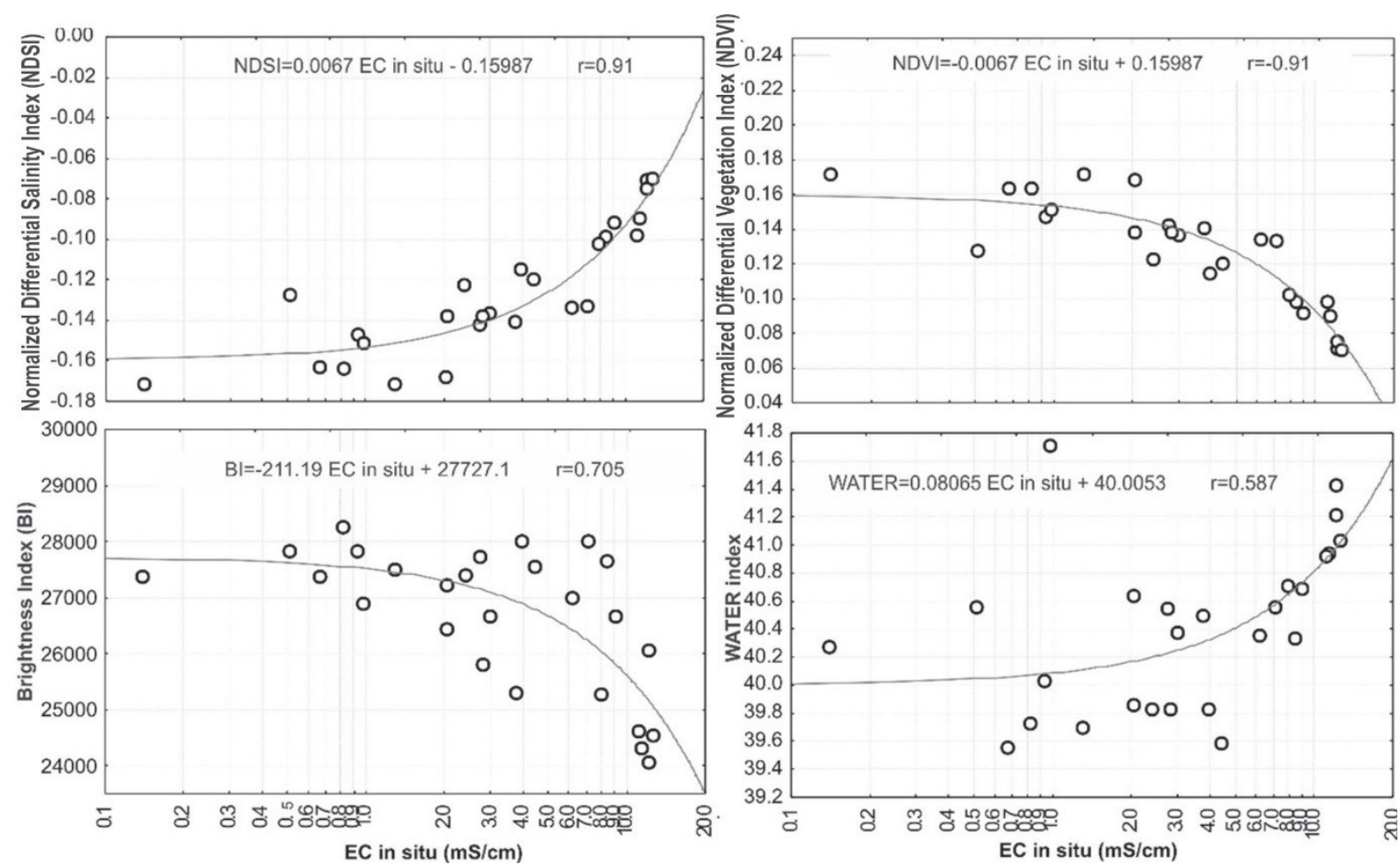

Fig. 3. Correlation between the indices NDSI, NDVI, BI, WI, and electrical conductivity in situ.

the indices obtained with the satellite image and the electrical conductivity measured in the soil, in order to characterize the study area.

\section{The Kalman Filter}

The Kalman filter (KF) is a recursive algorithm that optimally estimates signals by filtering white gaussian noise [37]. It can be seen as a low-pass filter [38]. The KF has been a tool successfully used in aerospace [39], data fusion [38], signals filtering, navigation [40], and control theory, among others.

The discrete linear system considered for the $\mathrm{KF}$ is as is shown:

$$
x_{k}=A_{k-1} x_{k-1}+W_{k-1}
$$

$$
y_{k}=C_{k} x_{k}+v_{k}
$$

...where $x_{k}$ describes the unknown signal. The measurement with white gaussian noise is described by $y_{k}$. The matrices $A_{k-1}$ and $C_{k}$ are factors and $W_{k-1}$, and $v_{k}$ represents uncertainties of white gaussian noise associated with the unknown signal and the measurement, respectively. Both are considered of zero mean, uncorrelated, and with matrices of variance $Q_{k-1}$ and $R_{k}$, respectively.

The KF for the linear system described above is given by

$$
\begin{gathered}
\hat{x}_{k}^{-}=A_{k-1} \hat{x}_{k-1}^{+} \\
P_{k}^{-}=A_{k-1} P_{k-1}^{+} A_{k-1}^{T}+Q_{k-1}
\end{gathered}
$$

\begin{tabular}{|c|c|c|c|c|c|c|}
\hline & EC in situ & Ec in laboratory & NDSI & NDVI & BI & WATER \\
\hline EC in situ & 1.00 & & & & & \\
\hline EC in laboratory & 0.96 & 1.00 & & & & \\
\hline NDSI & 0.91 & 0.85 & 1.0 & & & \\
\hline NDVI & -0.91 & -0.85 & -1.0 & 1.0 & & \\
\hline BI & -0.71 & -0.65 & -0.6 & 0.6 & 1.00 & \\
\hline WATER & 0.59 & 0.58 & 0.5 & -0.5 & -0.55 & 1.00 \\
\hline
\end{tabular}

Table 3. Correlation matrix of salinity indices and EC in situ and laboratory

Bold correlations are significant at $\mathrm{p}<.050$ 

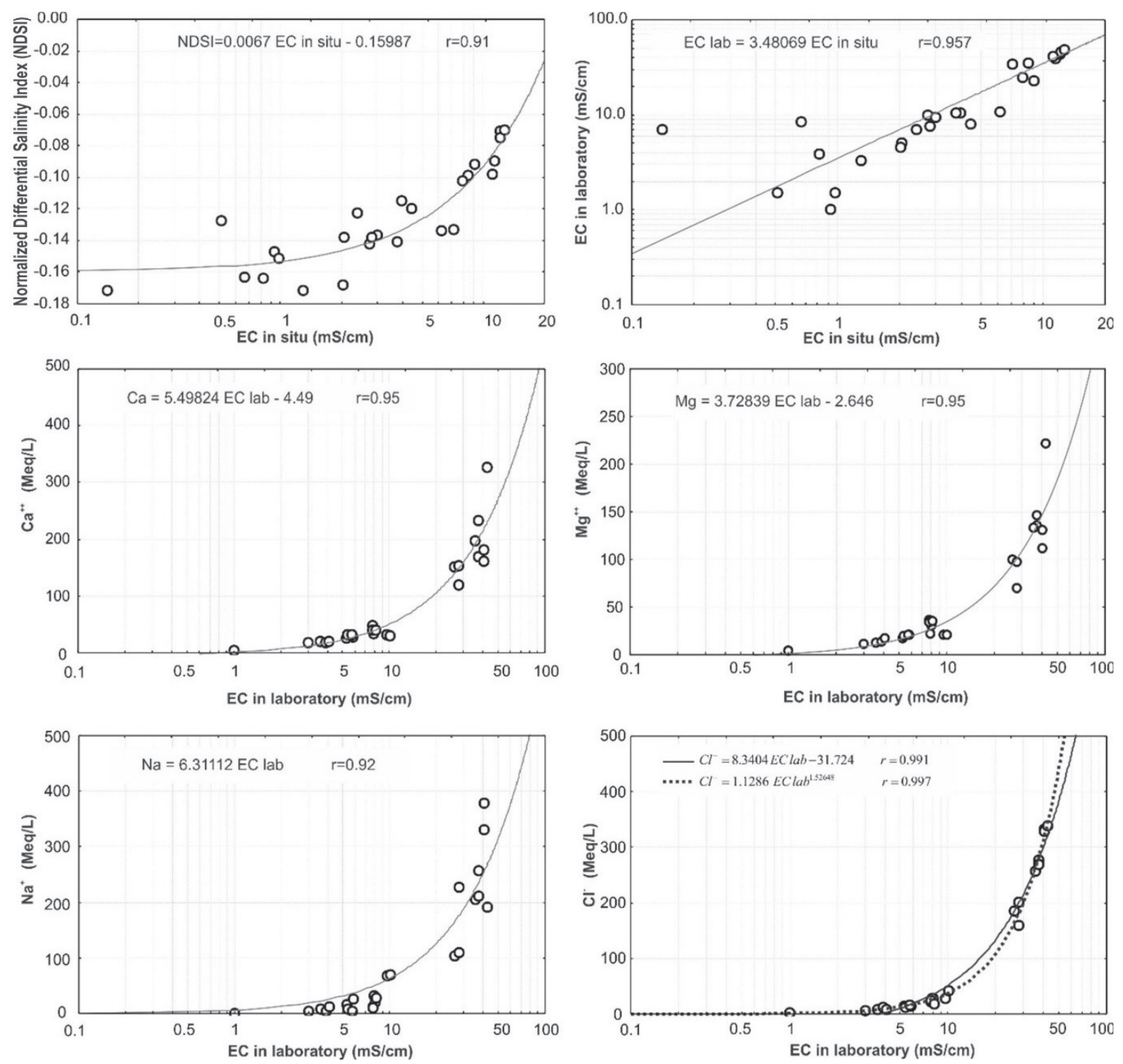

Fig. 4. Correlations between EC and concentrations of ions.

$$
\begin{gathered}
K_{k}=P_{k}^{-} C_{k}^{T}\left(C_{k} P_{k}^{-} C_{k}^{T}+R_{k}\right)^{-1} \\
\hat{x}_{k}^{+}=\hat{x}_{k}^{-}+K_{k}\left(y_{k}-C_{k} \hat{x}_{k}^{-}\right) \\
P_{k}^{+}=P_{k}^{-}-K_{k} C_{k} P_{k}^{-}
\end{gathered}
$$

...where $\hat{x}_{k}^{-}$is the estimate signal of $x_{k}$ before processing the measurement $y_{k}$ in the instant $k . P_{k}^{-}$is the variance of the estimation error $\hat{x}_{k}^{-} . K_{k}$ is the optimization factor, usually named Kalman gain. $\hat{x}_{k}{ }^{+}$describes the estimate signal of $x_{k}$ after processing the measurement $y_{k}$ in the instant $k$ and $P_{k}^{+}$is the variance of the estimation error $\hat{x}_{k}^{+}$.

For the particular case of this work that correspond to signals filtering, the system (1) and (2) as well as the $\mathrm{KF}$ are specified with the matrices $A_{k-1}=I_{8 * 8}$, $C_{k}=I_{8^{*} 8}, Q_{k-1}=0.1 / I_{8^{*} 8}, R_{k}=0.1 / I_{8^{*} 8}$ and initial conditions $\hat{x}_{k}^{+}=\left[\begin{array}{lllllllll}1 & 0.93 & 0.1 & 0.1469 & 5 & 3.5 & 0.5 & 1.6 & 2\end{array}\right]^{T}$ and $P_{0}=I_{8 * 8}$.

\section{Results and Discussion}

Relationship between Salinity and Electrical Conductivity Indices in situ

Twenty-six points were located at which electrical conductivity was measured in situ and for each point we determined the BI, NDVI, NDSI, and water, which can be seen in Table 2. By means of the use of simple correlation, the salinity indices with the electrical conductivity of the soil were analyzed, finding significant differences for the indices NDSI $(r=0.91)$, NDVI $(\mathrm{r}=-0.91)$, BI $(\mathrm{r}=-0.71)$, and water $(\mathrm{r}=0.59)$, which can be seen in Fig. 3. Table 3 shows that the NDSI salinity index used in this work was the one that obtained the highest correlation with the electrical conductivity of the soil, so it was used to characterize the salinity in the study area and is given by the expression:

$$
\mathrm{NDSI}=0.006698 \mathrm{EC} \text { in situ }-0.15986
$$


Table 4. Behavior of electrical conductivity and anions and cations in the study area

\begin{tabular}{|c|c|c|c|c|c|c|c|c|c|c|c|c|c|}
\hline \multirow{3}{*}{ No. } & \multirow{3}{*}{$\mathrm{pH}$} & \multicolumn{6}{|c|}{ OBTAINED IN LABORATORY } & \multicolumn{6}{|c|}{ FILTERED DATA } \\
\hline & & \multirow{2}{*}{ EC lab } & \multicolumn{5}{|c|}{ SOLUBLE IONE (Meq/lt) } & \multirow{2}{*}{ EC lab } & \multicolumn{5}{|c|}{ SOLUBLE IONE (Meq/lt) } \\
\hline & & & $\mathrm{Ca}^{2+}$ & $\mathrm{Mg}^{2+}$ & $\mathrm{Na}^{+}$ & $\mathrm{HCO}_{3}^{-}$ & $\mathrm{Cl}^{-}$ & & $\mathrm{Ca}^{2+}$ & $\mathrm{Mg}^{2+}$ & $\mathrm{Na}^{+}$ & $\mathrm{HCO}_{3}^{-}$ & $\mathrm{Cl}^{-}$ \\
\hline 1 & 6.9 & 1 & 5 & 3.5 & 0.5 & 1.6 & 2 & 1.0 & 5.0 & 3.5 & 0.5 & 1.6 & 2.0 \\
\hline 2 & 7.5 & 8.4 & 40 & 30 & 40 & 1.6 & 20 & 7.9 & 47.4 & 35.5 & 12.0 & 1.1 & 21.4 \\
\hline 3 & 7.3 & 5 & 25 & 15 & 10 & 0.7 & 15 & 5.3 & 26.1 & 17.2 & 16.2 & 1.0 & 14.6 \\
\hline 4 & 7.5 & 10 & 50 & 45 & 35 & 1.1 & 20 & 8.0 & 40.0 & 29.5 & 20.4 & 1.2 & 28.0 \\
\hline 5 & 7.6 & 1.5 & 8 & 5 & 1 & 1.3 & 2.5 & 1.0 & 5.0 & 3.5 & 0.5 & 1.6 & 2.0 \\
\hline 6 & 7.4 & 3.3 & 18 & 9.5 & 4.5 & 2 & 7 & 3.6 & 19.0 & 12.1 & 7.1 & 1.7 & 7.5 \\
\hline 7 & 7.3 & 10.5 & 65 & 50 & 15 & 0.8 & 30 & 9.6 & 31.5 & 20.7 & 67.8 & 1.0 & 29.0 \\
\hline 8 & 7.5 & 3.9 & 22.5 & 10 & 5.5 & 0.8 & 6 & 3.9 & 18.9 & 13.3 & 4.5 & 1.0 & 11.6 \\
\hline 9 & 7.4 & 1.5 & 8 & 5 & 1 & 0.9 & 2.5 & 3.0 & 17.2 & 10.6 & 3.7 & 0.9 & 6.1 \\
\hline 10 & 7.4 & 4.5 & 20 & 15 & 5 & 1 & 15 & 4.1 & 20.6 & 16.2 & 11.2 & 1.2 & 8.4 \\
\hline 11 & 7.1 & 6.9 & 40 & 25 & 5 & 0.8 & 20 & 5.4 & 32.0 & 19.7 & 8.0 & 0.9 & 11.9 \\
\hline 12 & 7.2 & 9.4 & 45 & 35 & 30 & 1.4 & 35 & 7.9 & 33.8 & 21.8 & 32.0 & 1.2 & 27.4 \\
\hline 13 & 7.1 & 7.6 & 40 & 35 & 5 & 1.7 & 20 & 5.9 & 28.0 & 20.9 & 26.5 & 1.6 & 13.8 \\
\hline 14 & 7.3 & 8 & 30 & 15 & 45 & 1 & 30 & 7.8 & 40.0 & 32.9 & 10.9 & 1.5 & 23.1 \\
\hline 15 & 7.9 & 10.6 & 30 & 20 & 90 & 0.8 & 30 & 10.1 & 30.6 & 20.3 & 69.2 & 0.9 & 42.0 \\
\hline 16 & 7.5 & 10.4 & 30 & 20 & 70 & 0.8 & 50 & 8.2 & 40.9 & 34.4 & 27.8 & 1.1 & 17.9 \\
\hline 17 & 7.2 & 39 & 175 & 100 & 325 & 0.6 & 300 & 37.3 & 169.4 & 134.7 & 256.8 & 0.6 & 277.8 \\
\hline 18 & 7.2 & 43 & 200 & 175 & 275 & 0.5 & 325 & 40.3 & 181.3 & 130.5 & 379.4 & 0.7 & 333.2 \\
\hline 19 & 7 & 46 & 425 & 275 & 150 & 0.5 & 375 & 40.7 & 161.9 & 111.6 & 330.3 & 0.7 & 328.1 \\
\hline 20 & 7.6 & 34 & 175 & 100 & 225 & 0.6 & 225 & 28.0 & 119.8 & 69.5 & 227.3 & 0.7 & 201.4 \\
\hline 21 & 7.4 & 35 & 175 & 125 & 200 & 0.7 & 250 & 35.9 & 197.2 & 133.2 & 204.6 & 0.7 & 256.9 \\
\hline 22 & 7.6 & 23 & 125 & 75 & 50 & 0.6 & 100 & 26.1 & 151.0 & 98.9 & 103.5 & 0.7 & 184.7 \\
\hline 23 & 7.3 & 25 & 150 & 100 & 100 & 0.8 & 200 & 27.9 & 152.6 & 97.2 & 109.0 & 0.6 & 159.9 \\
\hline 24 & 7 & 49 & 200 & 150 & 550 & 0.6 & 425 & 42.7 & 327.4 & 221.4 & 190.8 & 0.5 & 337.9 \\
\hline 25 & 7.3 & 41 & 150 & 100 & 300 & 0.7 & 325 & 37.3 & 233.2 & 146.4 & 211.9 & 0.6 & 268.1 \\
\hline 26 & 8.1 & 7 & 25 & 15 & 30 & 1.5 & 30 & 5.8 & 31.9 & 20.5 & 4.8 & 0.9 & 16.8 \\
\hline
\end{tabular}

Fig. 4 also shows that the electrical conductivity of the soil in laboratory (EClab) can be correlated with that obtained in situ, finding a lineal relationship of equation 9, with an adjustment of $r=0.957$.

$$
E C_{l a b}=3.48069 \cdot E C_{\text {in situ }}
$$

Determining Relationships between Electrical Conductivity in Laboratory, $\mathrm{pH}$, and Some Ions

From the values obtained in the laboratory of $\mathrm{Ce}$, $\mathrm{pH}$, and concentrations of the ions of $\mathrm{Cl}^{-}, \mathrm{Na}^{+}, \mathrm{Ca}^{++}$, and $\mathrm{Mg}^{++}$found in Table 4, we observed the strong correlation between $\mathrm{Ce}$ lab and $\mathrm{Cl}^{-}, \mathrm{Na}^{+}, \mathrm{Ca}^{++}$, and
$\mathrm{Mg}^{++}$. Once you know the electrical conductivity of the soil, it is possible to estimate each of the elements analyzed for the study area, with the exception of $\mathrm{pH}$, for which no significant differences were found with an adjustment of $r=-0.29$ (see Table 5).

Likewise, when comparing the NDSI index it provides greater accuracy in the study area, so that from their values obtained, they are correlated with the electrical conductivity of the soil and with the concentrations of $\mathrm{Cl}^{-}, \mathrm{Na}^{+}$, and $\mathrm{Ca}^{++}$, as well as $\mathrm{Mg}^{++}$ ions determined in laboratory. In Fig. 4 these concentrations are observed, obtaining a higher correlation between electrical conductivity and the chloride ion $(r=0.99)$. 
Table 5. Correlation matrix $\mathrm{pH}$, CElab, and some ions

\begin{tabular}{|c|c|c|c|c|c|c|c|}
\hline & & $\mathrm{pH}$ & EC lab & $\mathrm{Ca}^{2+}$ & $\mathrm{Mg}^{2+}$ & $\mathrm{Na}^{+}$ & $\mathrm{Cl}^{-}$ \\
\hline \multirow{6}{*}{ OBTAINED IN LABORATORY } & $\mathrm{pH}$ & 1 & & & & & \\
\hline & EC lab & -0.29 & 1 & & & & \\
\hline & $\mathrm{Ca}^{2+}$ & -0.35 & 0.9 & 1 & & & \\
\hline & $\mathrm{Mg}^{2+}$ & -0.38 & 0.91 & 0.99 & 1 & & \\
\hline & $\mathrm{Na}^{+}$ & -0.26 & 0.89 & 0.65 & 0.68 & 1 & \\
\hline & $\mathrm{Cl}^{-}$ & -0.35 & 0.99 & 0.89 & 0.9 & 0.91 & 1 \\
\hline \multirow{5}{*}{ FILTERED DATA } & EC lab & & 1 & & & & \\
\hline & $\mathrm{Ca}^{2+}$ & & 0.95 & 1 & & & \\
\hline & $\mathrm{Mg}^{2+}$ & & 0.95 & 0.99 & 1 & & \\
\hline & $\mathrm{Na}^{+}$ & & 0.93 & 0.80 & 0.81 & 1 & \\
\hline & $\mathrm{Cl}^{-}$ & & 0.99 & 0.94 & 0.95 & 0.95 & 1 \\
\hline
\end{tabular}

Bold correlations are significant at $\mathrm{p}<.050$

In this way, the relationships between electrical conductivity and the concentrations of anions and cations previously determined in the laboratory are obtained and make faster calculations, and the linear correlation was determined and in the case of chloride, the exponential was also performed.

In equations $10,11,12,13$, and 14 the equations are observed, obtaining greater adjustment with the chloride, sodium, calcium, and magnesium ions with an r greater than 0.91 .

$$
\begin{gathered}
\mathrm{Cl}^{-}=8.3404 \mathrm{EC} \mathrm{lab}-31.724 \\
\mathrm{Cl}^{-}=1.12386 \mathrm{EC} \mathrm{lab}^{1.52648} \\
\mathrm{Na}^{+}=6.31112 \mathrm{EC} \mathrm{lab} \\
\mathrm{Ca}^{++}=5.49824 \mathrm{EC} \mathrm{lab}-4.49 \\
\mathrm{Mg}^{++}=3.72839 \mathrm{EC} \mathrm{lab}-2.646
\end{gathered}
$$

\section{Determining Ions as from Salinity Index}

Practically, from the values of the NDSI it is possible to estimate the electrical conductivity in situ and from this, the value of the electrical conductivity in laboratory and estimate the concentration of the ions $\mathrm{Cl}^{-}, \mathrm{Na}^{+}, \mathrm{Ca}^{++}$, and $\mathrm{Mg}^{++}$.

In Figs 5, 6, 7, and 8, the concentrations of saline ions were estimated within the study area in addition to being able to map and compare them with the prediction of NDSI to each of the ions: $\mathrm{Cl}^{-}, \mathrm{Na}^{+}, \mathrm{Ca}^{++}$, and $\mathrm{Mg}^{++}$.

Chlorine is absorbed by the plant in the form of chloride ion, in suitable concentrations, from 0.2 to $0.4 \mathrm{mg} / \mathrm{g}$ in most plants, it contributes as an essential factor for photosynthesis, in addition to developing a regulatory role in stomatal opening, acting as a cation neutralizer and reducing the effect of diseases caused by fungi. While in excessive amounts, it causes thinning of leaves and even dries plants, being a factor that limits the growth of plants in arid and semi-arid soils [41]. Fig. 3 shows the correlation of the chlorine ion with electrical conductivity. It presents an average of $110 \mathrm{Meq} / \mathrm{1}$, presenting a minimum of $2 \mathrm{Meq} / \mathrm{l}$ and a maximum of $225 \mathrm{Meq} / 1$ in the sodic saline areas, in the map of Fig. 5 which is shown on the left, it is observed the map of the estimates as from the values of the NDSI index.

On the other hand, sodium can be beneficial during periods of drought, since it slows plant wilt while maintaining the cellular osmotic potential, as well as being beneficial in the soil structure when dispersing clays [41]. Sodium has a critical role in soil health, and excessive amounts of sodium affect the physical structure of soil because it aggregates fragmenting by causing a decline in water and air permeability of soil, adversely affecting root development [42, 43]. The same behavior is observed in both comparative maps of Fig. 6, of the analyzed samples, an average of 98.8 Meq/1 was obtained showing in agriculture regions minimum levels of $0.5 \mathrm{Meq} / 1$, while in arid regions, values of $550 \mathrm{Meq} / \mathrm{l}$.

Meanwhile, calcium is generated by several types of rocks, of mother rock, mainly its abundance is found in function of the presence of organic matter present in soil, to a lower content of organic matter, the greater the presence of this mineral [28]. It is the cation of greater abundance in soil, it improves in plants the development of leaves and roots, activates enzyme-forming systems, in addition to reducing nitrate in plants [32], Fig. 7 shows the comparative maps for the cation $\mathrm{Ca}^{++}$, which presents a similar behavior than the prediction of the NDSI to the 


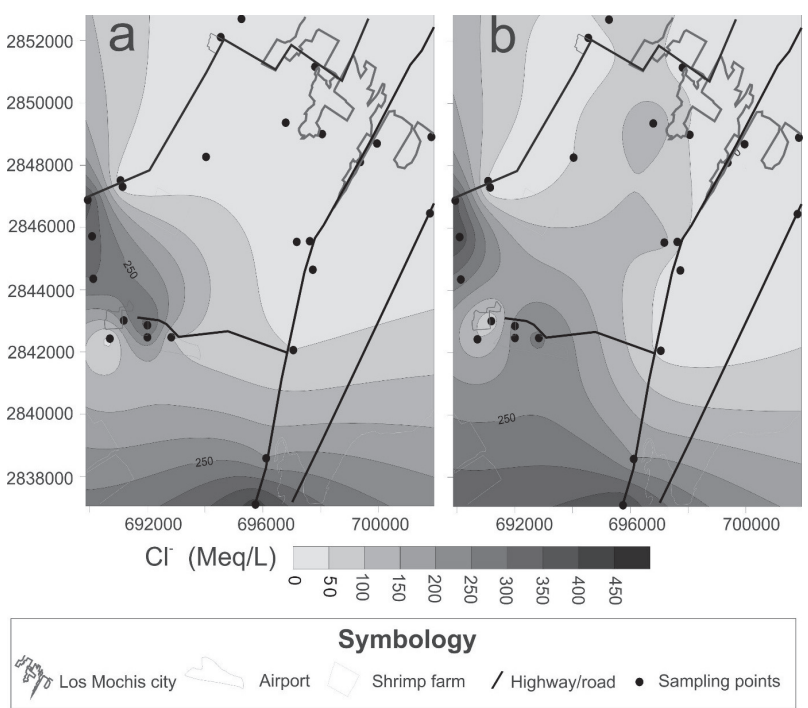

Fig. 5. Comparative map of concentrations of $\mathrm{Cl}^{-}$: a) concentration measured in laboratory and b) estimated concentration as from NDSI.

concentrations obtained in laboratory presenting a maximum value of $425 \mathrm{Meq} / 1$ in areas marked as saline.

The accumulation of magnesium in its ionic form $\mathrm{Mg}^{++}$can occur by the same nature of soil as with calcium, as well as by using water with high concentrations for irrigation use helping raise the sodium level in clays. However, at toxic levels it acts as a flocculant, in addition to reducing plant growth and promoting the dispersion and expansion of clay due to the loss of water-conducting properties [33], comparative maps of the concentrations of $\mathrm{Mg}^{++}$are observed in Fig. 8, which present a similar significance to the

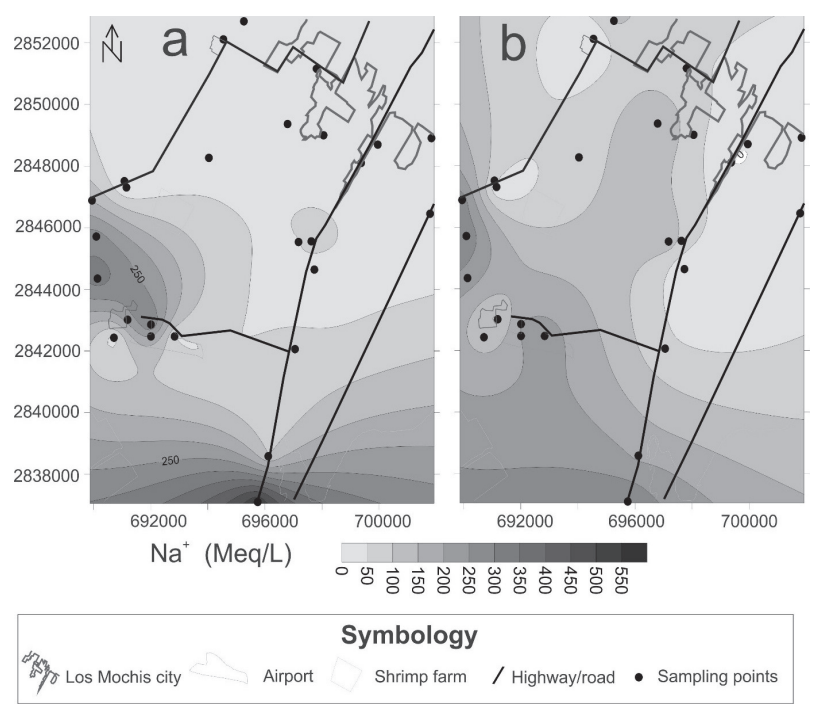

Fig. 6. Comparative map of $\mathrm{Na}^{+}$concentrations: a) concentration measured in laboratory and b) estimated concentration from NDSI.

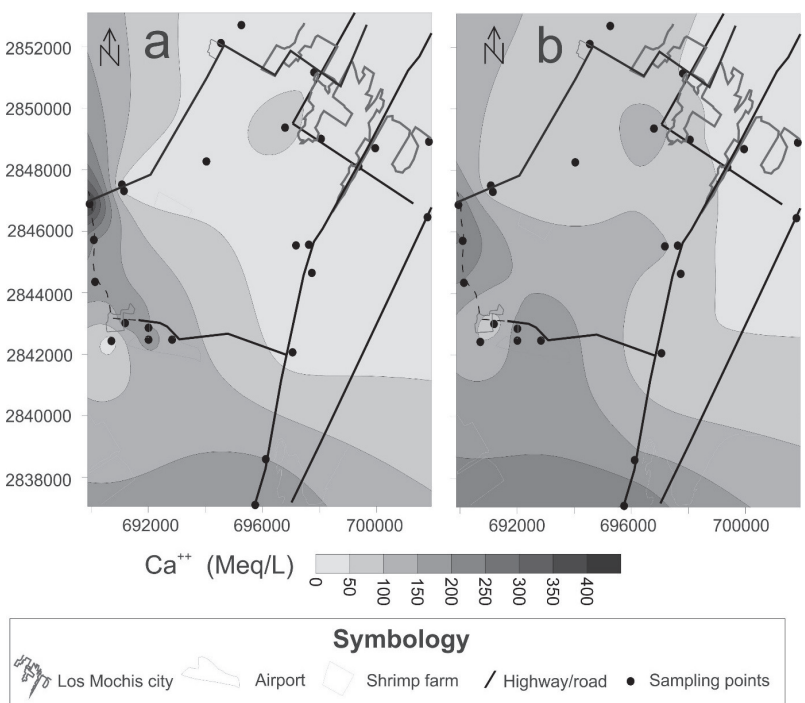

Fig. 7. Comparative map of $\mathrm{Ca}^{++}$concentrations: a) concentration measured in laboratory and b) estimated concentration as from NDSI.

estimate from the NDSI index to that obtained in laboratory, which presents low levels in an average of $59.7 \mathrm{Meq} / \mathrm{l}$.

According to the classification of salinity proposed by Richards [44] and the points taken in the study area shows that most of the area presents problems of salinity which varies from slightly saline to strongly saline. Small portions of non-saline soils were found to the north and northeast of the study area. The application of classification of soils considering the classification of Richards has been used by diverse authors [4, 45-47] in diverse geological environments and is useful for classifying the risk of salinity of the soils. The Kalman

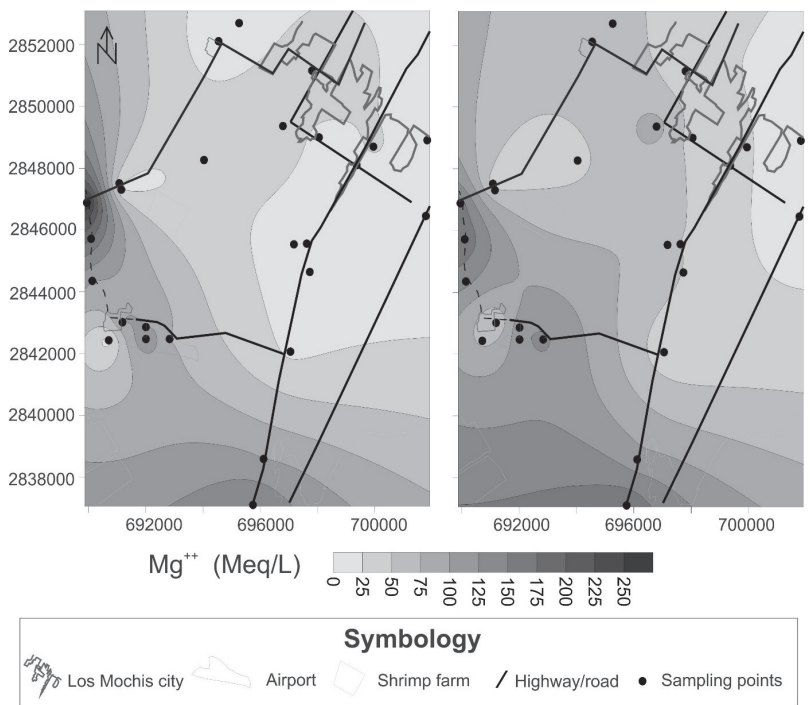

Fig. 8. Comparative map of concentrations of $\mathrm{Mg}^{++}$: a) concentration measured in laboratory and b) estimated concentration starting from NDSI. 


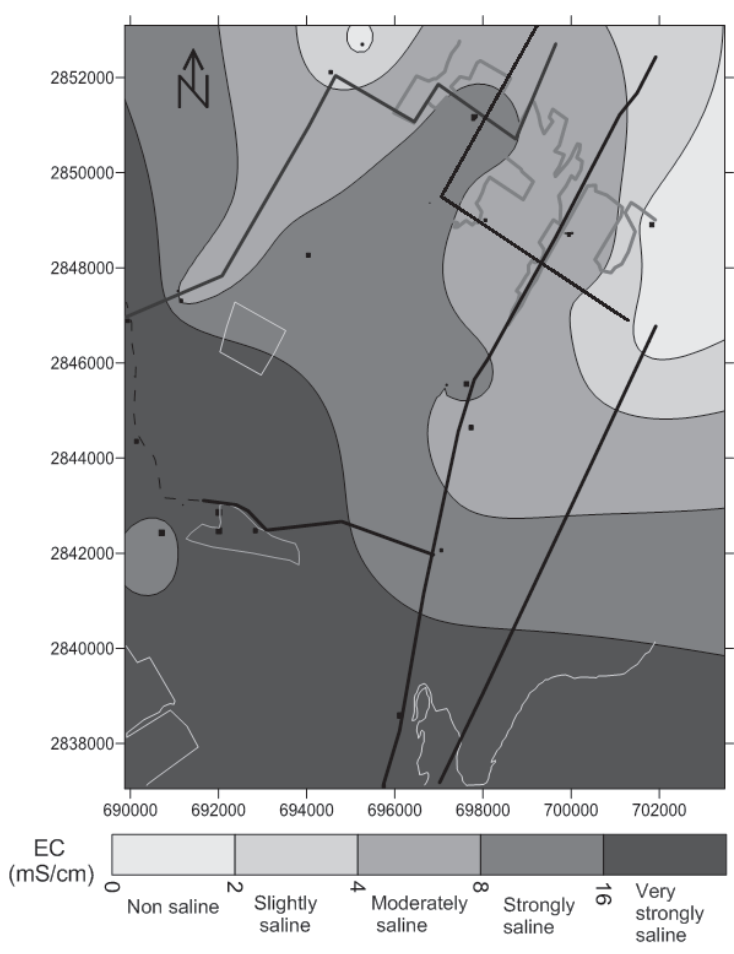

Fig. 9. Behavior of soil salinity in the study area.

filter is useful for eliminating dispersity in a variable's relationships [48].

\section{Practical Application}

Taking the NDSI values and using the previous models (Equations 8 to 14), as can be seen in Table 6 , it is possible to determine the concentrations of chlorine, sodium, calcium, and magnesium by means of interpolations of values between the correlations from the NDSI and electrical conductivity within the study area, which makes it favorable in the practical agricultural application, that is, in the control of soil nutrients required by the crop.

\section{Conclusions}

In regions where agricultural activities predominate, the NDSI index presents better results to detect the

Table 6. Practical examples of the application of the study.

\begin{tabular}{|c|c|c|}
\hline NDSI & -0.1 & \\
\hline $\mathrm{EC}$ in situ $=(\mathrm{NDSI}+0.15986) / 0.006698$ & 8.937 & $\mathrm{mS} / \mathrm{cm}$ \\
\hline $\mathrm{EC} \mathrm{lab}=3.48069 \mathrm{EC}_{\text {in situ }}$ & 31.106 & $\mathrm{mS} / \mathrm{cm}$ \\
\hline $\mathrm{Na}^{+}=6.31112 \mathrm{EC} \mathrm{lab}$ & 196.31 & $\mathrm{Meq} / \mathrm{l}$ \\
\hline $\mathrm{Cl}^{-}=8.3404 \mathrm{EC} \mathrm{lab}-31.724$ & 227.71 & $\mathrm{Meq} / 1$ \\
\hline $\mathrm{Ca}^{2+}=5.49824 \mathrm{EC} \mathrm{lab}-4.49$ & 166.53 & $\mathrm{Meq} / 1$ \\
\hline $\mathrm{Mg}^{2+}=3.72839 \mathrm{EC}$ lab-2.646 & 113.33 & $\mathrm{Meq} / 1$ \\
\hline
\end{tabular}

degree of salinity than the BI and water index. On the whole, with the NDSI index, electrical conductivity, interchangeable ion concentrations (previously filtered with the Kalman filter) and statistical functions, it is possible to determine the degree of salinity and concentration of interchangeable ions in the soil, and any point in the study area. On the other hand, the water index proves to be a good indicator in the presence of wet areas by flood or low phreatic level, which together with the NDSI index allows for the determination of saline areas caused by irrigation with salt water or by leaks of water of the same characteristics.

Of the anions and cations examined, the chloride ion had a higher correlation with electrical conductivity, which represents a greater ease of detection in the NDSI index. However, it is important to note that this is not only found alone, and therefore also functions as an indicator of the presence of the other analyzed ions.

\section{Acknowledgements}

The authors thank the Laboratory of Soil and Water of the National Water Commission for its support with the soil and groundwater laboratory, and to the Autonomous University of Sinaloa for its valuable assistance in completing this investigation.

\section{Conflict of Interest}

The authors declare no conflict of interest.

\section{References}

1. ASFAW E., SURYABHAGAVAN K.V., ARGAW M. Soil salinity modeling and mapping using remote sensing and GIS: The case of Wonji sugar cane irrigation farm, Ethiopia. Journal of the Saudi Society of Agricultural Sciences, 21 (May), 1, 2016.

2. GORJI T., SERTEL E., TANIK A. Monitoring soil salinity via remote sensing technology under data scarce conditions: A case study from Turkey. Ecological Indicators, 74, 384, 2017.

3. CEPEDA D.J. Soil Chemistry. Trillas. 2012 [In Spanish].

4. DALIAKOPOULOS I.N., TSANIS I.K., KOUTROULIS A., KOURGIALAS N.N., VAROUCHAKIS A.E., KARATZAS G.P., RITSEMA C.J. The threat of soil salinity: A European scale review. Science of the Total Environment, 573, 727, 2016.

5. PORTA-CASANELLAS J. Edafologia-use and protection of soils. (S.A. M.P. Libros, Ed.) (3rd ed.), 2014 [In Spanish].

6. DING J., YU D. Monitoring and evaluating spatial variability of soil salinity in dry and wet seasons in the Werigan-Kuqa Oasis, China, using remote sensing and electromagnetic induction instruments. Geoderma, 235-236, 316, 2014.

7. SCUDIERO E., SKAGGS T.H., CORWIN D.L. Comparative regional-scale soil salinity assessment with near-ground apparent electrical conductivity and remote 
sensing canopy reflectance. Ecological Indicators, 70, 276, 2016.

8. ALDABAA A.A.A., WEINDORF D.C., CHAKRABORTY S., SHARMA A., LI B. Combination of proximal and remote sensing methods for rapid soil salinity quantification. Geoderma, 239, 34, 2015.

9. METTERNICHT G.I., ZINCK J.A. Remote sensing of soil salinity: Potentials and constraints. Remote Sensing of Environment. 2003.

10. FARIFTEH J., VAN DER MEER F., VAN DER MEIJDE M., ATZBERGER C. Spectral characteristics of saltaffected soils: A laboratory experiment. Geoderma, 145 (3-4), 196, 2008.

11. BLASCH G., SPENGLER D., HOHMANN C., NEUMANN C., ITZEROTT S., KAUFMANN H. Multitemporal soil pattern analysis with multispectral remote sensing data at the field-scale. Computers and Electronics in Agriculture, 113, 1, 2015.

12. OPEKAR F., TŮMA P. Dual-channel capillary electrophoresis for simultaneous determination of cations and anions. Journal of Chromatography A, 1446, 158, 2016.

13. ROMERO F.S. Satellite remote sensing and environmental protection systems Introduction. Revista AquaTIC, 24, 13. Retrieved from http://www.revistaaquatic.com/aquatic/art. asp? $\mathrm{t}=\mathrm{p} \& \mathrm{c}=196, \mathbf{2 0 0 6}$ [In Spanish].

14. WU W., MHAIMEED A.S., AL-SHAFIE W.M., ZIADAT, F., DHEHIBI B., NANGIA V., DE PAUW E. Mapping soil salinity changes using remote sensing in Central Iraq. Geoderma Regional, 2-3, 21, 2014.

15. ZEWDU S., SURYABHAGAVAN K.V., BALAKRISHNAN M. Geo-spatial approach for soil salinity mapping in Sego Irrigation Farm, South Ethiopia. Journal of the Saudi Society of Agricultural Sciences, 16 (1), 16, 2017.

16. FLORES R.S., WILLEMS B.L., OCOLA L.C., FERNÁNDEZ R., PÉREZ J.C. Identification of land degraded by soil salinity in sugarcane crops using satellite images. Revista de Investigación de Física, 19, 0, 2016 [In Spanish].

17. POENARU V., BADEA A., CIMPEANU S.M., IRIMESCU A. Multi-temporal Multi-spectral and Radar Remote Sensing for Agricultural Monitoring in the Braila Plain. Agriculture and Agricultural Science Procedia, 6, 506, 2015.

18. SHRESTHA R.P. Relating soil electrical conductivity to remote sensing and other soil properties for assessing soil salinity in northeast Thailand. Land Degradation and Development, 17 (6), 677, 2006.

19. KHAN N.M., RASTOSKUEV V.V, SATO Y., SHIOZAWA S. Assessment of hydrosaline land degradation by using a simple approach of remote sensing indicators. In Agricultural Water Management 77, 96, 2005.

20. LAISKHANOV S.U., OTAROV A., SAVIN I.Y., TANIRBERGENOV S.I., MAMUTOV Z.U., DUISEKOV S.N., ZHOGOLEV A. Dynamics of soil salinity in irrigation areas in South Kazakhstan. Polish Journal of Environmental Studies, 25 (6), 2469, 2016.

21. DEHNI A., LOUNIS M. Remote sensing techniques for salt affected soil mapping: Application to the Oran region of Algeria. In Procedia Engineering. 33, 188, 2012.

22. JAYALAKSHMI S., VELAPPAN E. Assessment of Water Quality Index in the St. Thomas Mount Block Using GIS and Remote Sensing. Polish Journal of Environmental Studies, 24 (4), 1611, 2015.
23. MORA J.L., HERRERO J., WEINDORF D.C. Multivariate analysis of soil salination-desalination in a semi-arid irrigated district of Spain. Geoderma, 291, 1, 2017.

24. INEGI. Statistical and geographical yearbook of Mexico 2016. National Institute of Statistics and Geography, 2016 [In Spanish].

25. IMPLAM. Atlas of Natural Risks of the city of Los Mochis 2011. Ahome, Sinaloa, México. 109, 2012 [In Spanish].

26. SAGARPA (Ministry of Agriculture, Livestock, Rural Development, Fisheries and Food). State Agroeconomic Indicators. Sinaloa, Méxco. 6, 2011 [In Spanish]

27. United States geological website. earthexplorer.usgs.gov/.

28. JOVANOVIĆ M.M., MILANOVIĆ M.M. Normalized difference vegetation index (NDVI) as the basis for local forest management. Example of the municipality of Topola, Serbia. Polish J. Environ. Stud. 24, 529, 2016.

29. ŽIVOTIĆ L., PEROVIĆ V., JARAMAZ D., DORDEVIĆ A., PETROVIĆ R., TODOROVIĆ M. Application of USLE, GIS, and remote sensing in the assessment of soil erosion rates in southeastern serbia. Polish J. Environ. Stud., 21, 1929, 2012.

30. SCUDIERO E., TEATINI P., CORWIN D.L., DEIANA R., BERTI A., MORARI F. Delineation of site-specific management units in a saline region at the Venice Lagoon margin, Italy, using soil reflectance and apparent electrical conductivity. Comput. Electron. Agric. 99, 54, 2013.

31. FAN X., LIU Y., TAO J., WENG Y. Soil salinity retrieval from advanced multi-spectral sensor with partial least square regression. Remote Sens. 7, 488, 2015.

32. SCUDIERO E., SKAGGS T.H., CORWIN D.L. Regional scale soil salinity evaluation using Landsat 7, Western San Joaquin Valley, California, USA. Geoderma Reg., 2, 82, 2014.

33. CIHLAR J. Land cover mapping of large areas from satellites: status and research. Int. J. Remote Sens., 21, 1093, 2000.

34. FASSBENDER H.W., BORNEMISZA E. Soil Chemistry: with emphasis on Latin American soils; Costa Rica, 1994 [In Spanish].

35. SEMARNAT. Official Mexican Standard Nom-021Semarnat-2000. It establishes the specifications of fertility, salinity and classification of soils, study, sampling and analysis; México. 85, 2002 [In Spanish].

36. BOUYOUCOS G.J. Hydrometer Method Improved for Making Particle Size Analyses of Soils. Agron. J., 54, 464, 1962.

37. KALMAN R.E. A New Approach to Linear Filtering and Prediction Problems. Journal of Basic Engineering. 1960.

38. KIM P. Kalman Filter for Begineers with MATLAB Examples. 2010.

39. GREWAL M.S., ANDREWS A.P. Applications of Kalman Filtering in Aerospace 1960 to the Present. IEEE Control Systems, 30 (3), 69, 2010.

40. BEKIR E. Introduction to modern navigation systems. Recherche. WORLD SCIENTIFIC. 2007.

41. NAVARRO-GARCÍA G., NAVARRO-GARCÍA S. Agricultural chemistry Essential soil and nutrient chemistry. (S.A.M.-P. LIBROS, Ed.). España. 2013 [In Spanish].

42. KARADAĞ S., EREN E., ÇETINKAYA E., ÖZEN S., DEVECI S. Optimization of sodium extraction from soil by using a central composite design (CCD) and determination of soil sodium content by ion selective electrodes. Eurasian J Soil Sci, 5 (2), 1, 2016. 
43. STOICA M.E., AVRAM L., ONUTU I., BARBULESCU A., PANAITESCU C. Time Behaviour of Hydrocarbon Pollutants in Soils Polluted with Oil and Salt Water. REV. CHIM.(Bucharest), 67 (2), 357, Retrieved from http://www. revistadechimie.ro 2016.

44. RICHARDS L. Diagnosis and Improvement of Saline and Alkali Soils.: Soil Science. Soil Science, 78 (2), 154, 1954.

45. LHISSOU R., EL A., CHOKMANI K. Mapping soil salinity in irrigated land using optical remote sensing data. Eurasian journal of science, 3 (2), 82, 2014.

46. İRİK H.A. Develi Ovası Toprak Tuzluluğunun Belirlenmesi ve Coğrafi Bilgi Sistemleri Kullanılarak Haritalanması.
(Doctoral dissertation, Selçuk Üniversitesi Fen Bilimleri Enstitüsü). Retrieved from http://acikerisim.selcuk.edu. tr:8080/xmlui/bitstream/handle/123456789/984/335304. pdf?sequence $=12013$.

47. HULISZ P., PIERNIK A. Soils affected by soda industry in Inowrocław. Technogenic soils of poland, 125. Retrieved from http://www.academia.edu/16807997/Soils_affected by_soda_industry_in_Inowrocław 2013.

48. SIMON D. Optimal state estimation: Kalman, H infinity, and nonlinear approaches. Wiley-Interscience, 2006. 